\title{
THE COOPERATION BETWEEN FAMILY AND SCHOOL AS AN IMPORTANT ASPECT IN THE DEVELOPMENT OF GIFTED CHILDREN
}

\author{
Gulnara Faritovna Gali ${ }^{1}$, Anastasiya Viktorovna Fakhrutdinova ${ }^{2}$, Gulsina Yakupovna Grevtsova ${ }^{3}$, Askar \\ Ilshatovich Gali ${ }^{4}$ \\ ${ }^{1,2,3,4}$ Candidate of Pedagogic Sciences, ${ }^{1,2,4}$ Kazan (Volga region) Federal University, Kazan, Russia, ${ }^{3}$ Chelyabinsk State \\ Institute of Culture and Arts, Russia. \\ E-mail: gulnaragali@mail.ru
}

Article History: Received on $15^{\text {th }}$ July 2019, Revised on $30^{\text {th }}$ August 2019, Published on $18^{\text {th }}$ September 2019

\begin{abstract}
Purpose of the Study: One of the important features of effective pedagogical school is the close cooperation of parents and teachers in the gifted students' educationworldwide. Cooperation represents a joint action and negotiation, which is aimed at finding solutions, and a new, common ground. Cooperation between schools and parents may be traditional and partnership-oriented. In what way it will be achieved and placed, depends on the legal regulations, school environment, professional competence and individual characteristics of teachers, sociodemographic, and psychosocial characteristics of the parents. The study aims to determine the teacher functions in cooperation between the family and school.

Methodology: The leading approaches to the study of this problem are: the method of historical and logical analysis of regulatory documents of foreign governments and research papers by leading scientists dealing with gifted education issues and the method of analysis, comparison, synthesis and generalization of innovative foreign, and domestic pedagogical experience.

Results: The paper is based on the assumption that parents do not participate in decision-making at the school and that the cooperation between family and school in primary schools is still traditional. The results showed that parents are not involved in decision-making at the school, and the cooperation between family and school is still traditional and that is mainly related to parent meetings and informative conversations, without involvement of the partnership.

Implication: The authors focus on the specifics of working with gifted students' parents, as well as on the analysis of the problems of gifted students' education in different countries. The studies confirm that the task of parents and teachers working with gifted students is to create the necessary conditions and environment in which the gifted students could successfully develop and learn to overcome various difficulties.
\end{abstract}

Novelty: Materials of the article can be useful for professors, teachers, students, and a wide range of readers interested in the problems of gifted students' education.

Keywords: Education, Gifted Children, Family, School, Cooperation, Communication, Partnership.

\section{INTRODUCTION}

The problem of giftedness constantly attracts the attention of educators and psychologists in the modern world. The education and development of gifted children, their adaptation to the challenges of modern society is one of the most urgent problems of modern pedagogy. According to many domestic and foreign researchers, it is also considered that for all children, the goal of education and upbringing is to provide conditions for the disclosure and development of their abilities. This goal is particularly significant concerning gifted children (Combs, 2009; Ratner, 2009).

The Higher Pedagogical School of Russia is a developed system of professional education. There is no doubt that the lack of teachers' training for working with gifted children and their parents is one of the urgent problems of higher pedagogical institutions in our country. This is because, in modern conditions, the demand has increased for socially active creative persons who can respond quickly to changes and produce original ideas (Fakhrutdinova, Fakhrutdinova, \& Severyanov, 2013). Undoubtedly, gifted children are a huge intellectual and creative potential of any country. To help them become individuals is the task of high schools and teachers working with them. According to Delishe and Galbraith, such support can be provided only by highly qualified teachers who work creatively and represent what gifted children are (Delishe \& Galbraith, 2002). It is obvious that not having special knowledge in the field of children's giftedness, teachers are not able to recognize the abilities of their gifted students. They do not know how to stimulate their development and provide qualified assistance to parents of gifted children. Moreover, the lack of professional qualifications of teachers in most cases restrains the development of a gifted child and causes intrapersonal and interpersonal conflicts (Boland \& Gross, 2007). 
It should be noted that since the 60 s of the 20th century in our country, there have appeared specialized classes and schools (for example, boarding schools for gifted children in Moscow, Novosibirsk, St. Petersburg, Yekaterinburg, Kazan), where children are selected based on their higher-level abilities. The most successful work with gifted children in our days is being built in advanced educational institutions (lyceums, colleges, gymnasiums, author's schools, schools with in-depth study of specific subjects, etc.).

In this regard, it is important to note that public institutions and teachers tend to constantly put interest in the problems of gifted students' education at the level of the country, regions, and specific educational institutions. This is reflected in the adoption of the state acts, as well as in the implementation of various author programs for the gifted students' training and development. A great number of new competitions and subject Olympiads for gifted students are held, which are the traditional way to identify academically gifted students (Vinnikova, Fakhrutdinova, \& Dulmukhametova, 2017). Motivating gifted schoolchildren to participate in Olympiads by teachers help students realize that Olympiads helps them not only confirm their primacy in knowledge, gain a sense of self-reliance, feel an interest in themselves, assess their knowledge, but also orient themselves to one or another sphere of professional activity and deepen interest in it (Sagitova, 2014).

Accordingly, it is very important to find out children's abilities in the family and at school to create favorable conditions for the development of each child. To do this, it is necessary to unite the efforts of all participants in the educational process (psychologists, teachers, and parents). Their central task is the formation and development of talented students' ability to self-actualization, to the effective implementation of increased opportunities in the future, and mature professional activity (Zeigler \& Raul, 2000).

To investigate this problem, the authors' used methods of historical and logical analyses of updated scientific sources.

Taking into consideration international experience, the authors analyze the effective forms and methods for preserving the intellectual and spiritual potential of gifted children.

The article aims to reveal the role of all the participants in the educational process (psychologists, teachers, and parents) and their main tasks, which manifest themselves in the formation and development of gifted children's ability to selfactualization, to the effective realization of their opportunities in the future, and mature professional activity.

\section{METHODS}

The objects of our investigation are: 1) to define the teacher functions in cooperation between the family and school; 2) to determine the current requirements for work with gifted students; 3 ) to study the international experience of working with gifted students to enhance the effectiveness of gifted students' education.

For confirmation of the hypothesis we need to turn to a variety of methods:

- The method of historical and logical analyses of regulatory documents of foreign governments and research papers by leading scientists connected with educational issues of gifted students' education;

- Study and theoretical analysis and synthesis of social, political, and psycho-pedagogical literature;

- Analysis, comparison, synthesis, and generalization of innovative foreign and domestic pedagogical experience;

- Comparison of foreign and domestic research data on this issue.

The fundamental works of foreign and Russian researchers in the field of pedagogy and psychology (Combs, Strip, Ratner, Sagitova, Fakhrutdibova, etc.) were the theoretical basis of our study.

The usage of the methodology and methods of existing research contributes to the development of scientific thought in education for gifted students. It provides the opportunity to comprehensively address the problem of gifted students' education.

\section{RESULTS}

Today, the education system has a special responsibility for supporting gifted students not only to maximize the talents of the gifted children, but also to use their intelligence and abilities, without compromising the development of the psyche and mental health. The formation of personality is a complex process. The development of certain fundamental human skills is achieved by transferring the basic cultural heritage on a child from early learning and communication with other family members. Children are introduced to the rules of social life and behavior of their society through socialization and individualization as a process by which they develop internal motivation system by following the personal characteristics of their personality (Ćatić, 2005). The most important role in the social environment is played by a family, and the school, as a secondary educational factor. Holders of the educational role of the family are the parents. 
Although the role of the mother and father have their specifics, the role of both parents is equally important for education in the upbringing of the child. So, families are primary, they are "educators of human nature because direct interaction takes place through them and children acquire their foundational learning experience" (Golubović, 1981).

At school, the fundamental role of education is played by a teacher. In this regard, it is important to note that the preparation of the teacher for work with gifted students should also include an aspect of working with gifted children' parents. The teachers should convince parents of the need for careful attention to their extraordinary children. Parents should help their children to overcome psychological problems in education and communication with peers (Craig \& Pepler, 2003).

Today, the most urgent issue is the close cooperation of parents and teachers in the education of gifted studentsworldwide. The development of any child, including a gifted one, cannot and should not be determined only by the work of the school. The role of the family is very important in this sense. Therefore, the full understanding and practical realization of the basic goals of education largely depends on expertly organized and pedagogically clear focused cooperation between families and schools. The initiative and the focus of activities in this cooperation belong to teachers, class teachers, professional associates (pedagogues and psychologists), and school principals. However, at present, even in schools that focus on working with gifted students, there is no program of work with the family of a gifted child. Meanwhile, many foreign authors point out that teachers working with gifted students need to learn to find contact with their parents, involve parents in the learning process of their children, and assist them in understanding the needs and aspirations of their children (VanTassel-Baska \& Feng, 2007; Clark, 2008). It is important to mention the fact that parents of gifted children need special training in the skills of interaction with their children and the tasks of teachers include the ability to skillfully inform parents about the success of their children's learning. According to the foreign authors, McAlpine and Reid, the best results in teaching gifted students can be achieved through close cooperation between parents, teachers, and psychologists (McAlpine, \& Reid 1996).

Cooperation makes it possible to always know what and how the students work, and how far the results of their work reach. According to Ćatić, developed forms of cooperation with educational institutions (parent-teacher meetings, lectures, school for parents, discussions, visiting family, individual, and group consultations) are in a great number of our schools, only partially in function and reduced mainly to the simplest communication of parents and educators, unfortunately (Ćatić, 2005).

There is a great interest given to the experience of US schools in working with gifted children's parents. A number of US researchers consider it appropriate to conduct various types of professional training with parents to provide them with the opportunity to identify and contribute to the development of the abilities and talents of their children, as well as assist them in the learning process (Ćatić, 2005; VanTassel-Baska \& Feng, 2007). It should also be noted that there are specialists in education in US schools for gifted children, and this is very important because they are involved in the process of communication with parents. Such a specialist is the link between a teacher and parents. This specialist has a special education and a clear understanding of the educational, social, and emotional needs of the gifted children. He can offer daily assistance to teachers and parents in solving many complex problems associated with gifted students. For example, if disagreement arises between the teacher and the parents, the specialist for gifted students offers neutral advice and inventive solutions (Strip, 2000).

American authors Delishe, Lewis and Lisovskis state that parents should be involved in the work of the school. In their opinion, the teacher while planning his work should include the following items:

- Meeting with parents several times a year. During meetings, teachers inform parents about their program, discuss the interests of gifted students' parents, as well as social and emotional needs, school planning, etc.

- Parent newsletter. It needs to be released several times a year so that parents are informed about what is happening in school and about trends in the education of gifted students.

- Protection of gifted children. It is necessary to involve parents in the creation of a society for the protection of gifted students. They will supervise school personnel, who must keep abreast of parental interests and support their participation in the gifted students' training.

- Voluntary opportunities. Parents should be invited to volunteer in class life and provide them with suitable education (Delishe, Lewis \& Lisovskis, 2002).

The studies confirm that the task of parents and teachers working with gifted students is to create the necessary conditions and environment in which the gifted could successfully develop and learn to overcome various difficulties. Regardless of the organizational form of cooperation between the school and the family, they must support each other, 
and also respect those educational functions that are specific to each of these educational institutions. Parents today realize the importance of assistance to be provided to their children, and educational institutions are obliged to help them in education (Higgins, 1994). "The parents understand the importance of assistance to be provided to their children. However, despite this, some help is not provided because of workload or the lack of necessary knowledge (education)" (Stevanović, 2000, p. 404). The cooperation of the school with the family must be programmed each school year. The schools should organize schools for parents, which have shown good results in many countries (Gali, Shakhnina, Zagladina, Belyaeva, Dulmukhametova, \& Ibragimova, 2018). The parents are no longer satisfied with mere formality reports on evaluations of their children. They want to learn how to help their children in certain subjects. They want to hear more about educational methods that they can apply in the family. Because of the importance of cooperation between family and school, the problem of research relates to the question: Do families and schools invest sufficient efforts to establish quality cooperation? Therefore, the study aimed to determine the teacher functions in cooperation between the family and school, whether the cooperation is still traditional or have established partnerships between families and schools.

\section{DISCUSSION}

The basic reason to make a detailed analysis of cooperation between parents and school is the specificity of gifted education. The research has shown that the problem is considered as one of the most important in the world. Of course, the special teacher training, i.e. professional and personal qualifications of teachers contribute to the effective solution of the problem of gifted students' education and development.

Various aspects of the problem of gifted students' development and education are reflected in the scientific work of foreign researchers: Kagan (2011), Passow (2009), Whitemore (2012), Renzulli (1982) and others. This problem was also considered by Russian researchers: Andreev (2010), Wolfson (2003), Dzhurinskiy (1999), Panov (2003), Savenkov (2000), Ratner (2009) and others. However, analysis of scientific papers on this issue showed us that this problem is not sufficiently considered.

\section{SUMMARY}

In the course of investigating this problem, the authors came to the following conclusions:

1. In modern pedagogical science and educational practice, the teaching and education of gifted students are often regarded as a global pedagogical task. Foreign countries have accumulated extensive experience in working with gifted students. The effective solution of the task of identifying, developing, and educating gifted students is, of course, facilitated by special teacher training.

2. The problem of preparing future teachers to work with gifted students is multifaceted and is largely determined by the needs of society. The preparation for future professional activity is nothing more than the formation of readiness for it, which implies a scientifically-based approach to the training of the gifted students, as well as to the solution of all issues relating to this area. A teacher's willingness to work with gifted students assumes that the teacher meets the special requirements:

- High communicative culture;

- The desire for self-education and self-improvement;

- Professional competence;

- The ability to find an approach to non-standard children;

- Goodwill, sensitivity, pedagogical tact;

- Knowledge of age psychology.

3. Detailed study of foreign teachers' experience with gifted students helps to improve the effect on the teaching process, education, and development of gifted students. In this regard, it is necessary to emphasize the positive innovations that have become widespread in pedagogics, abroad, for further analysis and identification of the organizational and pedagogical conditions and the usage of foreign experience in the domestic practice of teacher training to work with creatively gifted students.

The research does not exhaust all the questions connected with the study of the theory and teaching practice and psychological problems of gifted children. It should be concentrated on developing gifted students and teacher training to work with them, which could be said as perspective for further study in this field. 


\section{CONCLUSION}

All above mentioned ideas allows us to conclude that working with gifted students is multifaceted. It requires further research. This problem must be solved taking into account specific socio-psychological circumstances. In our opinion, giftedness is so individual and unique that the question of the optimal conditions for the development of each child should be considered separately. Accordingly, it is very important to identify gifted children in the family and at school and create favorable conditions for the development of the personality of each child. For this, it is necessary to unite the efforts of all participants in the educational process (psychologist, teacher, and parents).

\section{AKNOWLEDGMENT}

The work is performed according to the Russian Government Program of Competitive Growth of Kazan Federal University.

\section{BIBLIOGRAPHY}

1. Boland, C.M., \& Gross, M.U.M. (2007). Counseling highly gifted children and adolescents. Austin, TX: Prufrock.

2. Clark, B. (2008). Growing up gifted: Developing the potential of children at home and at school. Upper Saddle River, NJ: Pearson Prentice Hall.

3. Combs, A. (2009). The professional education of teachers: A perceptual view of teacher preparation. Boston: Allyn \& Bacon.

4. Craig, W.M., \& Pepler, D.J. (2003). Identifying and targeting risk for involvement in bullying and victimization. Canadian Journal of Psychiatry, 48, 577-582.

5. Delishe, J., \& Galbraith, J. (2002). When gifted kids don't have all the answers: How to meet their social and emotional needs. Minneapolis, MN: Free Spirit.

6. Delishe, J.R., Lewis, B.A., \& Lisovskis. M. (2002). The survival guide for teachers of gifted kids: how to plan? Manage and evaluate programs for gifted youth. Minneapolis: Free Spirit Publishing.

7. Fakhrutdinova, E., Fakhrutdinova, A., \& Severyanov, O. (2013).The transformation of educational approaches at the time of social and economical changes. World Applied Sciences Journal, 27(13), 15-19.

8. Gali, G., Shakhnina, I., Zagladina, E., Belyaeva, E., Dulmukhametova, G., \& Ibragimova A. (2018). The Specificity of Gifted Students' Teaching: Overseas Data: Proceedings of INTCESS 2018- 5th International Conference on Education and Social Sciences, Turkey, Istanbul, 5-7 February (pp.25-31).

9. Ćatić, R. (2005). Osnovi porodične pedagogije. Zenica: Faculty of Pedagogy.

10. Golubović, Z. (1981). Porodica kao ljudska zajednica. Zagreb: Naprijed.

11. Higgins, G.O. (1994). Resilient adults: Overcoming a cruel past. San Francisco: Jossey-Bass.

12. McAlpine, D. (2004). The identification of gifted and talented students. Palmerston North: Kanuka Grove Press.

13. McAlpine, D., \& Reid N. (1996). Teacher observation scales for identifying children with special abilities. Wellington: NZCER.

14. Ratner, F.L. (2009). Issues of personal talent in foreign and domestic pedagogy. Socialization of gifted students in the modern educational space, 6, 22-26.

15. Sagitova, R.R. (2014). Training students to be autonomous learners. International Journal of Humanities Education, 12 (1), 27-34.

16. Stevanović, M. (2000) .Obiteljska pedagogija. Varaždinske: Toplice.

17. Strip, C.A. (2000). Helping gifted children soar: a practical guide for parents and teachers. USA: Great Potential Press Inc.

18. VanTassel-Baska, J., \& Feng, A. (2007). The development and use of a structured teacher observation scale to assess differentiated best practice. Roeper Review, 19 (2), 89-92.

19. Vinnikova, M., Fakhrutdinova, A., \& Dulmukhametova, G. (2017). Modern Use Of The Pedagogical Technology Team-Teaching In The Training Of Teacher Candidates. Quid-Investigacion Ciencia Y Tecnologia, 28, 767-772.

20. Zeigler, A., \& Raul, T. (2000). Myth and reality: A review of empirical research studies on giftedness. High Ability Studies, 11 (2), 113-136. 